\title{
The First Norwegian Climate Litigation
}

Professor dr. juris Ivar Alvik

Scandinavian Institute of Maritime Law

The Faculty of Law, University of Oslo

\section{Introduction}

The first Norwegian chapter in the series of climate lawsuits around the world was instigated before the Oslo City Court in 2016, by the two environmental organizations Greenpeace Nordic and Natur og Ungdom ("Nature and Youth"). ${ }^{1}$ Before the oral hearing in November of 2017, another organization, Besteforeldrenes klimaaksjon (the "Grandparents' Climate Campaign"), also joined the suit. The court found in favour of the government, but the judgment has been appealed and is currently pending before the Appellate Court, after direct appeal to the Supreme Court was denied. As the case is on appeal, the following does not seek to go into any detailed analysis of the legal issues in the case but merely to give a brief introduction to the case.

The more specific claim of the three environmental organizations concerned the alleged invalidity of the awarding of licenses under the $23^{\text {rd }}$ license round for petroleum exploration and exploitation on the Norwegian Continental Shelf ("NCS") in 2016. A controversial aspect of these licenses is that they are in the far-north Arctic region of the NCS, in the southern and south-eastern part of the Barents Sea.

Legally, the case relies primarily on Section 112 of the Norwegian constitution, which has the following wording:

Every person has the right to an environment that is conducive to health and to a natural environment whose productivity and diversity are maintained. Natural resources shall be

\footnotetext{
${ }^{1}$ Judgment by Oslo tingrett (the Oslo City Court) 4 January 2018, TOSLO-2016-166674, available at https://lovdata.no/dokument/TRSIV/avgjorelse/toslo-2016-166674 (only in Norwegian).
} 
managed on the basis of comprehensive long-term considerations which will safeguard this right for future generations as well.

In order to safeguard their right in accordance with the foregoing paragraph, citizens are entitled to information on the state of the natural environment and on the effects of any encroachment on nature that is planned or carried out.

The authorities of the state shall take measures for the implementation of these principles.

The claimants made three partly interrelating claims: first, that the awarding of the licenses was invalid for being in direct violation of Section 112 of the Constitution, second, that it was invalid for being in violation of the Petroleum Act as interpreted in light of Section 112, and third, that it was invalid due to violation of several procedural requirements interpreted in light of Section 112: specifically, that it was based on insufficient impact assessments and factual mistakes, and that the reasons for the decision were not sufficiently stated.

The alleged factual basis for the claim was the almost universally perceived urgent need to reduce climate gas emissions from fossil fuels to save the world's climate. The Claimants generally maintained that the climate consequences of petroleum exploration and exploitation in the vulnerable arctic sea had not been sufficiently taken into account by the government when the area was opened and the licenses awarded. The consequences of potential future production for emissions in Norway was however considered and taken into account when the licenses were awarded. Thus, the essential basis of the claim was really the alleged failure to specifically consider the consequences of a potential increase in global production of oil and gas, as a result of new discoveries under the licenses. While it was also maintained that oil and gas production in the arctic posed particular environmental threats and was particularly $\mathrm{CO} 2$ intensive, it may be argued this was not essential to the claimant's case. Oil and gas from the northern regions does not, obviously, as such contain more $\mathrm{CO} 2$ than oil and gas from other regions, and emissions connected with production of a given quantity of oil and gas is quite marginal in comparison with total emissions from use and consumption of the same amount of oil and gas. Thus, the real thrust of the Claimants' arguments was the alleged lack of responsibility assumed by the Norwegian government, for emissions from consumption in other countries of Norwegian produced oil and gas. 
If the claimant's position had been accepted, or if it should ultimately prove to be successful in the higher courts, this might, unsurprisingly, have quite profound consequences for both Norwegian oil and gas production and other environmentally sensitive industries, such as fisheries, mining and energy production. What was and is at issue in the case is really the allocation of decision making power between the political authorities and the courts in matters concerning global climate policy and the environment. Should appropriate policies and measures to safeguard the world's climate primarily be a matter for the political authorities, the parliament and the executive, to decide upon and take into account in concrete matters, or are these matters fit for judicial review by the courts? And can and should the courts feel free to overturn government decisions giving rights to private persons and companies if these should be found to conflict with climate and environmental concerns? In the present case, there was no doubt that the licenses in question had firm parliamentary approval, and they had been the subject of an ordinary and thorough licensing, including an impact assessment of environmental consequences and risks. With these concerns in mind it may not be particularly surprising that the court ruled as it did, and it would indeed be surprising if the judgment of the first instance should be overturned in the higher courts. The judgment nevertheless makes several interesting and not entirely uncontroversial findings, which shall be further reviewed and commented upon in the following.

\section{The Licensing Process and Requirements}

Before we go into the judgment and the court's more concrete findings, it may be convenient to briefly explain the Norwegian licensing process for petroleum licenses. Before a license may be granted in a certain area, a decision must always have been taken to open that general area for petroleum activities, cf. the Norwegian Petroleum Act Section 3-1. ${ }^{2}$ This decision requires an impact assessment as to likely and potential environmental and economic consequences of petroleum activities in the area. ${ }^{3}$ Although it is always prepared by the

\footnotetext{
${ }^{2}$ Available in unofficial English translation at http://www.npd.no/en/Regulations/Acts/Petroleum-activities-act/

${ }^{3}$ See the specific requirements in the Petroleum Regulation, Section 6a-6d, available in unofficial English translation at http://www.npd.no/en/Regulations/Regulations/Petroleum-activities/
} 
Ministry of Petroleum and Energy, it must be presented to and approved by the Norwegian parliament (the Storting), which consequently makes the final decision as to whether an area is to be opened for petroleum activities. ${ }^{4}$

The licenses argued to be invalid in this case were Production Licenses, which is the central license in the Norwegian licensing system, cf. the Petroleum Act Section 3-3. This is usually granted either through ordinary bi-annual license rounds for "immature" areas, as in the present case, or yearly Awards in Predefined Areas (APA-licenses) for mature areas. The award of licenses is always preceded by a public announcement and application process, which again is subject to more distinct requirements forming the basis for the government's decision to award specific licenses (or in practice, shares in licenses, since licenses in practice are always awarded to a license group composed by the government from the applicant oil companies). ${ }^{5}$ The Production License (somewhat counterintuitively) gives a right and a duty to explore the license area, through a further defined exploration programme in the license, but it does not give a right to produce. Specifically, it does not give a definite right to develop a potential discovery into a producing field. This again requires a new decision from the Ministry; in the form of an approval of the so called Plan for development and Operation, which is prepared by the license group and is again subject to further procedural requirements. ${ }^{6}$ It must amongst other things take into account and assess both the economic prospects and environmental consequences of developing the resource into a producing field. ${ }^{7}$

Both the decision to open new areas, and the decision to develop a certain discovery for production, requires assessments of environmental consequences and risks. But there is no distinct requirement in the licensing procedure to the effect that an assessment must be made of the consequences of increased production of oil and gas for the world's climate in general. ${ }^{8}$

\footnotetext{
${ }^{4}$ The Petroleum Regulation, Section $6 \mathrm{~d}$.

${ }^{5}$ The Petroleum Act, Section 3-5; and the Petroleum Regulation, Sections 7-10.

${ }^{6}$ The Petroleum Act, Section 4-2.

${ }^{7}$ Cf. the Petroleum Regulation Section 22, and especially Section 22a-22c.

${ }^{8}$ The Petroleum Regulation, Section 6c (e) refers to «the climate» as one of several consequences that shall be considered in the impact assessment before a decision to open new areas is taken, but it is fairly clear that this
} 
The impact assessments made in respect of the disputed licenses thus considered only emissions in connection with the production in Norway (e.g. through flaring, and burning of gas to power the installations,) which were held to be marginal in comparison with total Norwegian emissions. They did not consider increased world emissions as a result of the potential increase in total production under these licenses. As mentioned, this was in reality the essence of the case made by the Claimants for the invalidity of the licenses.

\section{The Court's Findings}

The court's finding in favour of the Government and holding the licenses to be valid, may not be the most interesting part of the judgment. It would as mentioned have been relatively surprising if the court had come to a different result. ${ }^{9}$ The court did however have some interesting comments on the interpretation of Section 112 of the constitution, essentially holding that it in principle gave rights to individuals. This was a contested issue, as the government had maintained that Section 112 cannot be interpreted to give individual rights. Thus, the court's decision here can be seen as a partial victory for the claimants.

It is however less certain what it means in practice, as the perceived individual right in question is extremely general. The court considered the standard of review to be quite lenient towards the government, especially when concerning decisions taken with express or implicit parliamentary approval. It is consequently very uncertain whether and to what extent the court's interpretation may in practice entail that specific individual interests are protected. A reasonable assumption would be that when a right belongs to everyone it is basically a collective interest that is protected, not individual interests in particular circumstances. One

cannot be interpreted to encompass an obligation to assess overall consequences for the world's climate resulting from increased Norwegian production of oil and gas as a result of opening new areas.

${ }^{9}$ Although see Ole Kristian Fauchald, 'Klimarettssaken og “amerikanisering” av norske domstoler' Lov og Rett vol. 57 no. 3 (2018) p. 158-169, at 169, who seem to be somewhat more open to the possibility of a different result. 
should therefore, perhaps, not read too much into the court's finding that Section 112 provides for individual rights.

This becomes clear when the court goes on to determine the more precise content of the right to a healthy environment. Essentially it held this had to be read in conjunction with the implementation obligation of the government in the third part of Section 112, which again had to be interpreted with a wide measure of deference to the government, being particularly wide in respect of measures adopted or maintained with parliamentary approval. The court even seems to have considered that the mere ascertainment that the said acts and measures had parliamentary approval in itself was sufficient to conclude that Section 112 was complied with, although it did go some way to show that the relevant environmental risks were not sufficiently serious to provide any limits on governmental discretion, and had also been adequately considered and taken into account by the government. In dismissing the claims, the court thus held that the awarding of the licenses was based on a policy firmly anchored in a broad parliamentary majority, confirmed by several parliamentary decisions, and that the licenses were subject to a number of actual or potential restrictions on allowed activities meant to safeguard the environment. Moreover, it found that both $\mathrm{CO} 2$ emissions and climate policy had been considered, both in relation to the opening of the area, and the award of the licenses. Therefore, there was no basis for considering the award of the licenses to be in direct breach of Section 112, nor for considering that environmental consequences had not been adequately considered and taken into account.

The most central and controversial part of the decision in this regard is that the court, after expressly problematizing and discussing this at some length, considered that Section 112 did not apply to $\mathrm{CO} 2$ emissions outside Norway from Norwegian produced oil and gas, i.e. it essentially allocated the responsibility for $\mathrm{CO} 2$ emissions exclusively to the consumers and demand side in line with the general allocation of responsibilities set out in the Paris Agreement. The court here refuted the main submissions of the claimants that also the potential increase in world climate gas emissions as a result of Norwegian petroleum exports had to be taken into account as a part of the responsibility of the Norwegian government, and that this should have been addressed before the decision to open new areas and grant new licenses were taken. 
It is not difficult to understand why the court reached this conclusion. If one concludes that emissions from Norwegian export in principle is covered by the government's responsibility under Section 112, this would again easily lead to the inference that increased emissions is a valid concern that should always be considered by the government when it opens new areas, issues licenses or approves development of new discoveries. It would effectively require the Norwegian petroleum authorities in every such case to weigh the benefits to the Norwegian population of increased income from petroleum exports, against the grave threat to the world's climate posed by a continued increase in emissions from the burning of fossil fuels. Without distinct criteria for global burden sharing, this would easily degrade into a rather pointless exercise. Seen in isolation, the increased risk involved to the world's climate from one or ten more Norwegian petroleum licenses will always be rather marginal, whereas the benefit may appear substantial and long lasting.

This may of course illustrate one of the challenges of combating climate change. The damage posed by increased production of oil and gas can be compared to throwing litter on the street. If everyone does it, it makes little difference if only one individual stops throwing litter. It is only if everyone or nearly everyone stops that a real difference is made. One may argue that if everyone is to stop, someone has to take the lead. But it may as forcefully be argued that for something like this to work, a collective agreement or consensus is needed. In any case, it makes little sense for any single government to sacrifice substantial economic benefits for its people to set an example which it is highly unlikely, in fact almost certain, no one else will follow. Moreover, such an almost entirely symbolic duty can almost certainly not be inferred from the Norwegian Constitution Section 112.

It may nonetheless be argued that the rather categorical rejection by the first instance court of any conceivable government responsibility under the Constitution for the consequences of Norwegian petroleum exports, goes too far. Such a distinction between emissions in Norway and emissions abroad has no basis in Section 112 itself, nor in the basic purpose and concerns underlying it as, essentially, a constitutional enshrinement of the environment as a legally protected interest. It could conceivably be argued that Section 112 also entails an obligation for the government to have a reasonable involvement in international participation to combat transboundary environmental threats. In this light is not entirely evident that Norway and the Norwegian government can just wash its hands of any responsibility for the consequences of 
increased production from the NCS, even though virtually all such production goes to export and consequently will almost entirely be turned into emissions in other countries.

It may of course be that the best solution for reducing emissions from fossil fuels is indeed to focus on demand, as seems to be the current international consensus. The theory would be that supply will adjust itself naturally according to demand, with the most expensive and least $\mathrm{CO} 2$ effective sources being the first to be reduced with falling demand. But this is clearly not something which can be read out of the Norwegian constitution as a predetermined legal principle. It has to be the subject of reasonable government assessments and decisions, in cooperation and negotiation with other governments around the world. One might in that regard conceivably envisage an international consensus emerging, or certain international measures being agreed, for targeting also supply and exports of fossil fuels to combat climate change. ${ }^{10}$ Something like this could for instance emerge through the dynamic development of national measures envisaged and encouraged by the Paris Agreement. In such case, there is no basis in my view for arguing that Section 112 distinguishes between transboundary environmental threats and consequences of Norwegian activities abroad, on the one hand, and purely local or national environmental consequences and threats, on the other. The most reasonable interpretation is that it in principle provides for the same kind of lenient, deferent standard of review in both cases, although a difference is of course that it may be easier to deal with the latter and that more may therefore usually be expected.

\section{Final remarks}

As mentioned in the introduction, the case has so far only been the subject of a first instance judgment. It is anybody's guess both how the appellate court will deal with the fundamental issues it raises, and whether it will in the final instance be appealed and subject to decision by the Norwegian Supreme Court. As the Supreme Court as a rule only admits cases involving fundamental issues or interests, admission of an eventual appeal is not a matter of course, although it may clearly be argued that the present case does raise issues of the gravest importance. However, the most important clarification that can be expected concerns the

\footnotetext{
${ }^{10}$ This point is also made by Fauchald (2018) p. 168.
} 
general issues regarding interpretation of Section 112 in the Norwegian constitution. On the facts, there is in my view little reason to expect that either the Appellate Court or the Supreme Court will find the Norwegian government to have violated its duties towards the environment in the present case. ${ }^{11}$ It is perhaps also for this reason a good case for the Supreme Court to use in order to start shaping the contours of Section 112 under Norwegian law. However, one may doubt whether it is a similarly good case for giving a legal push to the global climate struggle, if that was the intention.

\footnotetext{
${ }^{11}$ Some Norwegian commentators seem to consider the result more open however, see in particular Fauchald (2018), and Jørn Øyrehagen Sunde, ‘Klimasøksmål og demokrati’ Nytt norsk tidsskrift vol. 34 no. 4 (2017) p. 354-365.
} 